Indonesian Journal of Legality of Law
e-ISSN : 2477-197X

\title{
ANALISIS HUKUM PENGADAAN BARANG DAN JASA TERHADAP PNS DALAM PERSPEKTIF TINDAK PIDANA KORUPSI
}

\section{Legal Analysis of Procurement of Goods And Services Agains Government Employee In The Perspective of Criminal Actions Of Corruption}

\author{
Muhammad Aksan', Marwan Mas², Ruslan Renggong ${ }^{2}$ \\ ${ }^{1}$ Kepolisian Daerah Provinsi Sulawesi Selatan \\ ${ }^{2}$ Program Studi Ilmu Hukum Program Pascasarjana Universitas Bosowa
}

Email: muhammadaksan30@gmail.com

Diterima: 10 September 2021/Disetujui: 21 Desember 2021

\begin{abstract}
ABSTRAK
Tipe penelitian yang digunakan dalam penelitian ini adalah tipe penelitian normatif. Tehnik pengumpulan data yakni Bentuk penelitian kepustakaan yaitu teknik pengumpulan data dengan cara mempelajari berbagai literatur baik buku artikel maupun materi kuliah yang diperoleh. Bentuk interview yaitu teknik pengumpulan data dengan cara melakukan wawancara dengan pihak-pihak yang berkompeten dan objek penelitian, serta meminta data-data kepada pihak yang terkait. Adapun hasil penelitian menunjukkan bahwa penyidikan tindak pindana korupsi adalah tindakan yang dilakukan untuk memberantas korupsi, namun dalam pelaksanaanya mengalami banyak hambatan dan tantangan baik dari segi aspek sumber daya manusia maupun dari aspek kondisi alam, dukungan dana dan sarana dan prasarana, sedangkan pada aspek sumber daya manusia, dapat dilihat banyaknya pegawai negeri sipil yang tidak berminat menjadi pejabat pengadaan barang dan jasa hal ini disebabkan jabatan yang memiliki resiko besar karena konsekkuensinya adalah terlibat dalam persoalan hukum di Indonesia.
\end{abstract}

Kata Kunci: Hukum Pengadaan, Barang dan Jasa, Pidana Korupsi

\section{ABSTRACT}

The type of research used in this study is the type of normative research. Data collection techniques, namely the form of library research, namely data collection techniques by studying various literature, both article books and course materials obtained. The form of interview is a data collection technique by conducting interviews with competent parties and the object of research, as well as requesting data from related parties. The results of the study show that investigating corruption crimes is an action taken to eradicate corruption, but in its implementation there are many obstacles and challenges both in terms of aspects of human resources and aspects of natural conditions, financial support and facilities and infrastructure, while in the aspect of resources. humans, it can be seen that there are many civil servants who are not interested in becoming officials in the procurement of goods and services. This is because the position has a big risk because the consequences are being involved in legal issues in Indonesia.

Keywords: Procurement Law, Goods and services, Corruption Crime

This work is licensed under Creative Commons Attribution License 4.0 CC-BY International license

\section{PENDAHULUAN}

Negara Indonesia merupakan suatu negara yang berlandaskan pada hukum dengan sistem demokratis dan didasarkan pada Pancasila serta Undang-Undang Dasar 1945, agar dapat terlaksananya pemberian pelayanan kepada masyarakat (public service) berupa pembangunan fisik maupun non fisik baik dalam pengadaan saranan dan prasarana tentunya perlu didukung oleh kegiatan pengadaan barang/jasa yang baik oleh pemerintah sebagai pengguna barang/jasa atau oleh badan usaha maupun orang-perorangan sebagai penyedia barang dan jasa. Dalam pengadaan barang/jasa oleh pihak pengguna agar terwujudnya barang/jasa yang mencapai kesepakatan baik waktu maupun harga serta kesepakatan-kesepakatan lainnya diperlukan metode serta proses tertentu dimana baik pihak pengguna dan pihak penyedia harus patuh terhadap etika serta norma pengadaan barang dan jasa yang berlaku (Adrian Sutedi, 2010). Perlu kita ketahui bahwa sistem pengadaan barang/jasa yang baik adalah yang mampu dalam pelaksanaannya menerapkan prinsip-rinsip tata pemerintahan yang baik (good governance) serta membawa efisiensi, efektivitas belanjan publik, namun masih terdapat hambatan-hambatan nyata ketika mewujudkan tata pemerintahan yang baik yaitu seperti tingginya angka penyalahgunaan keuangan negara oleh 
oknum-oknum yang tidak bertanggung jawab sehingga menimbulkan kerugian terhadap negara yang cukup besar.

Pengadaan barang dan jasa pemerintah merupakan aktivitas yang sangat penting dalam mewujudkan pembangunan di Indonesia. Perkembangan pembangunan di Indonesia tidak dapat dilepaskan dari pengadaan barang dan jasa. Pemenuhan kebutuhan barang dan jasa merupakan bagian penting yang tidak dapat dipisahkan dalam penyelenggaraan pemerintahan.

Dalam kegiatannya, pengadaan barang/jasa ternyata dapat menimbulkan implikasi negatif yang baik dilakukan oleh Pejabat Pembuat Komitmen (PPK), Pokja (kelompok kerja) maupun oleh pihak penyedia/rekanan yang seringkali dipicu akan persekongkolan antara pejabat pengadaan dengan penyedia barang/jasa untuk mendapatkan keuntungan dengan bermain curang. Permasalahan yang seringkali timbul dalam pelaksanaan pengadaan barang/jasa yaitu kasus mark-up yang terletak pada penyerahan perhitungan HPS (harga perkiraan sendiri) oleh PPK dengan tanpa melakukan pengecekan kembali, kepada penyedia barang/jasa atau makelar dengan melipatgandakan harga barang pabrik yang sudah pasti memiliki harga yang berbeda dengan harga distributor maupun harga pasaran guna memperoleh keuntungan pribadi ataupun kelompok.

Dalam implementasinya prosedur pengadaan barang dan jasa terkadang tidak dilakukan sesuai dengan prosedur yang berlaku dan mengakibatkan terjadinya banyak penyimpangan dalam pelaksanaan pengadaan barang dan jasa pemerintah. Penyimpangan tersebut sekarang sudah semakin luas, hal ini terlihat dari banyaknya pihak yang terkait dengan pengadaan barang dan jasa yang akhirnya harus berurusan dengan aparat penegak hukum atas dasar penyimpangan yang sudah dilakukannya.

\section{METODE}

\subsection{Tipe Penelitian}

Tipe penelitian yang digunakan dalam penelitian ini adalah tipe penelitian normatif, yaitu menggunakan pendekatan perundang- undangan (statute approach) Pendekatan perundang-undangan untuk menelaah semua undang-undang dan regulasi (kebijakan hukum pidana) khususnya yang berkaitan dengan pengadaan barang dan jasa.

\subsection{Lokasi Penelitian}

Dalam rangka memperoleh data yang relevan dengan kebutuhan penulisan tesis ini, penulis akan melakukan penelitian di Polres Kepulauan Selayar.

\subsection{Fokus Masalah Penelitian}

a. Bagaimanakah pelaksanaan penyidikan tindak pidana korupsi di bidang pengadaan barang dan jasa oleh Polres Kepulauan Selayar?

b. Faktor apakah yang menghambat dalam penyidikan tindak pidana korupsi di bidang pengadaan barang dan jasa?

\subsection{Jenis dan Sumber Data}

Adapun jenis dan sumber data yang digunakan sebagai dasar untuk menunjang hasil penelitian adalah :

1. Data primer yaitu data yang diperoleh secara langsung dari sumber pertama (responden) pada lokasi penelitian.

2. Data Sekunder yaitu data yang diperoleh berupa sumber-sumber tertentu, seperti dokumen-dokumen termasuk juga literatur bacaan lainnya yang sangat berkaitan dengan pembahasan penelitian ini.

\subsection{Instrumen Penelitian}

Dalam penelitian menggunakan pendekatan kualitatif, oleh sebab itu instrumen penelitian adalah peneliti sendiri. Diharapkan melalui Peneliti sendiri sebagai instrumen penelitian ini mendapatkan data yang valid dan reliable. Disamping peneliti sebagai instrumen penelitian, instrumen penelitian menggunakan beberapa alat kelengkapan yang meliputi: (1) pedoman wawancara, (2) lembar observasi, serta (3) catatan dokumen.

Langkah-langkah yang dilakukan dalam rangka pengembangan instrumen, khususnya pedoman wawancara dan daftar pertanyaan yang diberikan kepada informan adalah:

a. Merumuskan fokus/inti masalah dan indikator dari masing-masing fokus.

b. Membuat tabel matriks pengembangan instrumen.

c. Membuat daftar pertanyaan dengan berpedoman/mengacu padadeskripsi fokus-fokus

2.6. Teknik Pengumpulan Data

1. Bentuk penelitian kepustakaan yaitu teknik pengumpulan data dengan cara mempelajari berbagai literatur baik buku artikel maupun materi kuliah yang diperoleh.

2. Bentuk interview yaitu teknik pengumpulan data dengan cara melakukan wawancara dengan pihak-pihak yang berkompeten dan objek penelitian, serta meminta data-data kepada pihak yang terkait dengan penelitian ini.

\subsection{Analisis Data}

Data yang diperoleh baik primer maupun sekunder dianalisis baik secara deduktif maupun induktif kemudian disajikan secara deskriptif yaitu menjelaskan, menguraikan, dan menggambarkan sesuai dengan permasalahan yang erat kaitannya dengan penelitian ini. Penelitian ini menggunakan pendekatan fenomenologi, sehingga teknik analisis data yang sesuai adalah teknik analisis kualitatif. Sedangkan langkah proses analisis data menggunakan analisis interaktif model Miles dan Huberman (2009).

\section{HASIL DAN PEMBAHASAN}

\subsection{Penyidikan Tindak Pidana Korupsi}

Dalam hal penegakan hukum tentang tindak pidana korupsi, polisi memiliki tugas sebagai penyidik, sebagaimana yang telah ditentukan dalam Kitab Undang-Undang Hukum Acara Pidana (KUHAP) Pasal 1 angka 1 bahwa yang dimaksud dengan penyidik adalah pejabat polisi negara Republik Indonesia atau pejabat pegawai negeri sipil tertentu yang diberi wewenang khusus oleh undang-undang untuk melakukan penyidikan, kemudian dipertegas dalam UU No. 2 tahun 2002 tentang Kepolisian Negara Republik Indonesia Pasal 14 angka 1 huruf g bahwa dalam melaksanakan tugas pokok, kepolisian negara Republik Indonesia bertugas melakukan penyelidikan dan penyidikan terhadap semua tindak pidana sesuai dengan hukum acara pidana dan peraturan perundang-undangan lainnya.Selain KUHAP dan UU tersebut dasar hukum lainnya yaitu Instruksi Presiden No. 5 tahun 2004, yang mana pada poin ke delapan dalam inpres tersebut disebutkan bahwa "memberikan dukungan maksimal terhadap upaya-upaya penindakan korupsi yang dilakukan oleh Kepolisian Negara Republik Indonesia, Kejaksaan Republik Indonesia dan Komisi Pemberantasan Korupsi dengan cara mempercepat pemberian informasi yang 
berkaitan dengan perkara tindak pidana korupsi dan mempercepat pemberian izin pemeriksaan terhadap saksi/tersangka."Dengan demikian polisi memiliki hak dan wewenang untuk menangani berbagai kasus korupsi. Tindak Pidana Korupsi mendapat perhatian lebih dari kepolisian sehingga dibentuk sebuah unit khusus untuk menangani kasus korupsi di setiap daerah yakni Unit Tindak Pidana Korupsi (tipikor).

Unit Tipikor berada di bawah kordinasi Satuan Reserse Kriminal yang merupakan unsur pelaksana tugas pokok dalam setiap kepolisian resort.Unit tipikor dibentuk khusus untuk menangani berbagai kasus korupsi yang terjadi dalam wilayah hukum kepolisian resort yang bersangkutan. Sebagaimana telah dijelaskan di awal bahwa korupsi merupakan ekstra ordinary crimesehingga dalam proses penyidikannya dibutuhkan penyidik dan pembantu penyidik dari pejabat polisi yang memiliki kapasitas serta memenuhi syarat sebagaimana telah ditetapkan dalam KUHAP.Menurut KUHAP yang berhak menjadi penyidik adalah pejabat kepolisian yang memenuhi syarat kepangkatan. Penjelasan tentang syarat kepangkatan ini dijelaskan lebih rinci melalui Peraturan Pemerintah (PP).

Langkah-langkah penyidikan tindak pidana korupsi oleh penyidik Kepolisian Negara Republik Indonesia tersebut di atas akan diuraikan sebagai berikut: (1) Persiapan penyidikan tindak pidana korupsi perlu langkah-langkah persiapan yang dilakukan dengan cara sebagai berikut :a.Penyusunan Laporan Kejadian Terjadinya Tindak Pidana Korupsi (LKTPK).b.Pembentukan tim penyidik dan penerbitan surat perintah penyidikan.c.Analisis Laporan Hasil Penyidikan Tindak Pidana Korupsi (LHPTPK). (2) Pemberitahuan Dimulainya Penyidikan Ketika Surat Perintah Dimulainya Penyidikan (SPDP) sudah diterbitkan, adalah kewajiban dari penyidik untuk memberitahukan dimulainya penyidikan kepada Jaksa Penuntut Umum yang biasa dikenal dengan Surat Pemberitahuan Dimulainya Penyidikan (SPDP). Norma ini diatur dalam Pasal 109 ayat (1) KUHAP.

Kondisi penyidikan di salah satu unit di Kepolisian di Selayar memperlihatkan bahwa belum optimalnya pelaksanaan penyidikan belum dapat berjalan secara maksimal dikarena beberapa factor yakni kondisi medan yang sulit terjangkau, komunikasi yang belum terbangun secara sinergis, adanya perbedaan pemahaman dan juga hal hal lain intinya SDM masih perlu ditingkatkan serta dukungan informasi yang actual guna pembuktian lebih akurat, selain itu di salah satu unit kepolisian di selayar antara lain pertama terkait jumlah personil di unit tipidkor yaitu hanya 4 orang sedangkan idealx adalah 9 orang.dua kualitas sdm dinilai dari jenjang pendidikan dimana belum ada personil tipidkor yang telah mengikuti pendidikan kejuruan penyikan korupsi ,belum ada yang mengikuti pelatihan pengadaan barang dan jasa serta hanya dua personil yg memiliki jenjang pendidikan S2 selebihnya masih tamatan SMA,dan terakhir adalah masa kerja atau pengalaman dimana hanya satu personil yang memiliki pengalaman kerja diatas lima tahun selebihnya masih dibawah dua tahun.

Sehingga dengan kondisi ini, penyidik yang berada di Unit Tipikor Satuan Reserse Kriminal pada Polres Kepulauan Selayar hanya dapat menyelesaikan 1 sampai 2 kasus tindak pidana korupsi dengan memperlihatkan data penyelesaian kasus sejak tahun 2017 sampai dengan tahun 2020.

Tabel 1. Daftar Kasus dan umlah Kerugian Negara

\begin{tabular}{|c|c|c|c|}
\hline No & Tahun & Nama Kasus & $\begin{array}{c}\text { Jumlah Kerugian } \\
\text { Negara }\end{array}$ \\
\hline 1. & 2017 & $\begin{array}{l}\text { Pengadaan Bangunan Gedung } \\
\text { Kantor Badan Penanggulangan } \\
\text { Bencana Daerah Kab Kep } \\
\text { Selayar T.A 2015 }\end{array}$ & $\begin{array}{l}\text { Rp. } 178.321 .759,60 .- \\
\text { (seratus tujuh puluh } \\
\text { delapan juta tiga ratus dua } \\
\text { puluh satu ribu tujuh ratus } \\
\text { lima puluh Sembilan } \\
\text { rupiah enam puluh sen) }\end{array}$ \\
\hline 2. & 2018 & $\begin{array}{l}\text { Penggunaan anggaran dds (dana } \\
\text { desa), anggaran add (alokasi } \\
\text { dana desa) dan pbhp } \\
\text { (penerimaan bagi hasil pajak) } \\
\text { pada desa pamatata kec. } \\
\text { Bontomatene kab. Kep. Selayar } \\
\text { sejak tahun anggaran } 2013 \\
\text { sampai dengan tahun anggaran } \\
2017\end{array}$ & $\begin{array}{l}\text { Rp. } 721.911 .865,92,- \\
\text { (tujuh ratus dua puluh } \\
\text { satu ribu Sembilan ratus } \\
\text { sebelas ribu delapan ratus } \\
\text { enam puluh lima rupiah } \\
\text { Sembilan puluh dua sen) }\end{array}$ \\
\hline 3. & 2019 & $\begin{array}{l}\text { Korupsi penggunaan anggaran } \\
\text { dds (dana desa), anggaran add } \\
\text { (alokasi dana desa) dan pbhp } \\
\text { (penerimaan bagi hasil pajak) } \\
\text { pada desa khusus pasitallu kec. } \\
\text { Taka bonerate kab. Kep. Selayar } \\
\text { tahun anggaran } 2015 \text { sampai } \\
\text { dengan } 2017 \\
\text { Korupsi Pengelolaan Anggaran } \\
\text { Pendapatan Dan Belanja Desa } \\
\text { Bontokoraang Kecamatan } \\
\text { Bontomanai Kabupaten } \\
\text { Kepulauan Selayar Tahun } \\
\text { Anggaran } 2016\end{array}$ & $\begin{array}{l}\text { Rp. 965.039.096,43,- } \\
\text { (sembilan ratus enam } \\
\text { puluh lima juta tiga puluh } \\
\text { sembilan ribu sembilan } \\
\text { puluh enam rupiah empat } \\
\text { puluh tiga sen) } \\
\text { Rp. 427.002.120,- (empat } \\
\text { ratus dua puluh tujuh juta } \\
\text { dua ribu seratus rupiah) }\end{array}$ \\
\hline 4. & 2020 & $\begin{array}{l}\text { Pengadaan Penerangan Lampu } \\
\text { Tenaga Surya Pada Beberapa } \\
\text { Desa Di Kab. Kep. Selayar } \\
\text { Tahun Anggaran } 2019\end{array}$ & $\begin{array}{l}\text { Rp. 2.390.260.000,- (dua } \\
\text { milyar tiga ratus sembilan } \\
\text { puluh juta dua ratus enam } \\
\text { puluh ribu rupiah) }\end{array}$ \\
\hline
\end{tabular}

\subsection{Pengadaan Barang dan Jasa}

Dalam Pasal 1 angka 1 Peraturan Presiden Nomor 4 Tahun 2015 Tentang Perubahan Keempat Atas Peraturan Presiden Nomor 54 Tahun 2010 tentang Pengadaan Barang/Jasa Pemerintah, dijelaskan bahwa pengertian pengadaan barang dan jasa pemerintah adalah kegiatan untuk memperoleh barang dan jasa oleh kementerian/lembaga/satuan kerja perangkat daerah atau institusi yang prosesnya dimulai dari perencanaan kebutuhan sampai diselesaikannya seluruh kegiatan untuk memperoleh barang dan jasa. Peraturan Presiden No. 4 Tahun 2015 tentang Perubahan Keempat Atas Peraturan Presiden No. 54 Tahun 2010 tentang Pengadaan Barang dan Jasa Pemerintah, merupakan aturan dasar yang mengatur tentang tata cara pengadaan barang dan jasa pemerintah serta dipakai sebagai acuan dalam melaksanakan proses pengadaan barang dan jasa pemerintah. Salah satu metode yang sering digunakan adalah melalui proses tender. Dalam proses tender ada suatu tahap penyeleksian yang dilakukan oleh pemerintah atau pengguna anggaran terhadap calon penyedia barang dan jasa. Tahap penyeleksian ini dilakukan untuk menetapkan satu pelaku usaha yang berhak memenangkan tender. 
Definisi pengadaan barang dan jasa menurut Kamus Besar Bahasa Indonesia (KBBI), adalah tawaran untuk mengajukan harga dan memborong pekerjaan atas penyediaan barang dan jasa.

\subsection{Pegawai negeri sipil banyak yang tidak mau menjadi pejabat pengadaan barang dan jasa di Kabupaten Kepulauan Selayar}

Adanya konsekuensi hukum dan besarnya resiko sebagai pejabat pengadaan barang dan jasa membuat banyak pegawai yang tidak ingin menduduki posisi tersebut, secara umum para pegawai menginginkan posisi yang nyaman, jauh dari resiko, sehingga pejabat pengadan barang dan jasa di anggap memiliki resiko yang besar artinya sedikit keliru dalam bertindak, maka implikasinya berurusan dengan hokum. sementara sudah menjadi rahasi umum bahwa Kebijakankebijakan yang dikeluarkan seringkali akan berbenturan dengan ketentuan hokum dikarenakan campur tangan dari pada pimpinan atas permintaan pihak ketiga/Rekanan sehingga berpotensi terjadinya Kecurangan yang menjadi awal dari terjadinya Tindak Pidana Korupsi.

\section{KESIMPULAN DAN SARAN}

Hasil penelitian dan pembahasan dapat disimpulkan bahwa penyidikan tindak pidana korupsi pengadaan barang dan jasa belum dapat berjalan secara optimal disebabkan banyaknya kendala baik dari segi dukungan sumber daya manusia maupun kondisi sarana dan prasaranana yang belum mendukung, selain itu juga faktor kondisi alam yang mana Kabupaten Kepulauan Selayar merupakan daerah yang dibatasi oleh laut sehingga kondisi alam juga memiliki pengaruh yang besar dalam proses penyelidikan tindak pidana korupsi. Banyaknya pegawai negeri sipil yang tidak mau menjadi pejabat pengadaan barang dan jasa di Kabupaten Kepulaun Selayar hal ini disebabkan karena banyaknya intervensi dari pimpinan dalam mengeluarkan kebiajakan serta sumber daya yang belum terbangun secara optimal sehingga pegawai tidak memiliki kompetensi dan mental yang prima untuk menduduki jabatan tersebut, selain adanya ketakutan bahwa jabatan tersebut memiliki risiko besar dan konsekwensinya adalah berurusan dengan hukum,sehingga proses pengadaan barang dan jasa pemerintah yang dilaksanakan dikabupaten kepulauan selayar berpotensi terjadi Korupsi

\section{DAFTAR PUSTAKA}

Adami Chazami, 2002, Pelajaran Hukum Pidana Bagian 1, Raja Grafindo Persada, Jakarta.

Adhi Ardian Kustiadi, 2006, Buku Panduan Mencegah Korupsi dalam Pengadaan Barang dan Jasa Publik, Jakarta: TI.

Adrian Sutedi, 2010, Aspek Hukum Pengadaan Barang/Jasa dan Berbagai Permasalahannya, Sinar Grafika, Jakarta.

Andi Hamzah, 1984, Korupsi di Indonesia Masalah dan Pemecahannya, PT Gramedia Pustaka Utama Jakarta, 1984

Buchari Said H, 2000, Sekilas Pandang Tentang Tindak Pidana Korupsi, Fakultas Hukum Universitas Pasundan Bandung.

Ensiklopedi, 2003, Hukum Islam, PT. Ichtiar Baru Van Hoeve, Jakarta, 2003.

E-Procurement. Diakses pada November 12, 2020, dari http://www.lkpp.go.id/v3/
Etika Pengadaan Barang dan Jasa. Diakses pada November 4, 2020, dari https://www.jogloabang.com/ekbis/perpres16-2018-pengadaan-barangjasa-pemerintah.

Heizer, J., and Render, B, 2011, Operations Management. 10th Edition. Pearson Education, Inc. New Jersey.

H. Subagya M.S, 2010, Manajemen Logistik. Jakarta : Toko Gunung Agung.

Jenis-Jenis Pengadaan barang dan jasa. Diakses pada November 3, 2020, dari https://bpkad.banjarkab.go.id/index.php/2017/02/22/jenis -jenis-pengadaan barang-dan-jasa-pemerintah/

Mochtar Lubis dan James C. Scott, 1995, Bunga Rampai Korupsi, Cet. Ke-3, LP3ES, Jakarta.

Moeljatno, 2008, Asas-asas Hukum Pidana, Jakarta: Rineka Cipta.

Pengadaan Barang dan Jasa. Diakses pada November 3, 2020, dari http://www.lkpp.go.id/v3/files/attachments/1_AdRQ sAeFlVOdLPKMYiDxPzorXXmSrSWj.pdf

Prinsip Pengadaan Barang dan Jasa. Diakses pada November 4, 2020, dari https://ngada.org/ps54-2010pjl.htm

Purwosusilo, 2014, Aspek Hukum Pengadaan Barang dan Jasa, Jakarta: Kharisma Putra Utama, 2014.

Robert Klitgaard, 2001, Membasmi Korupsi, Alihbahasa Hermoyo, Cet. Ke-2 Yayasan Obor Indonesia, Jakarta, 2001.

Ruslan Renggong, 2019, Hukum Pidana Khusus, Edisi Revisi, Prenad Media Group, Jakarta.

R. Tresna. 1990. Azas-azas Hukum Pidana. PT. Tiara. Jakarta. 1990.

S. H. Alatas, 1986, Sosiologi Korupsi Sebuah Penjelajahan Dengan Data Kontemporer, LP3ES, Jakarta, 1986.

Schravendijk, H.J. Van dan J.B. Wolters. 1985. Buku Pelajaran tentang Hukum Pidana Indonesia. Jakarta: Gronien.

Suherman.A.M., 2017, Pengadaan barang dan jasa (Government Procurement) perspektif kompetisi, kebijakan ekonomi, dan hukum perdagangan internasional, Ed.1 Cet 2, Rajawali Pers, Depok.

Tata Cara Pemilihan Penyedia Barang. Diakses pada November 4, 2020, dari https://www.bphn.go.id/data/documents/10pr054.pdf

Unsur-unsur Tindak Pidana Korupsi. Diakses pada November 5, 2020, dari https://www.kpk.go.id/images/pdf/Undangundang/uu311999.pdf

Undang-undang RI Nomor 31 Tahun 1999 Pemberantasan Tindak Pidana Korupsi, Citra Umbara, Bandung, 2003, hlm. 80-84.

William Allan Neilson (editor in chief), Webster's Third New Internasional Dictionary, Vol 1., hlm. 599.

W. J. S. Poerwodarmito, 1976, Kamus Umum Bahasa Indonesia, Balai Pustaka, Jakarta, 1976.

W. J. S. Poerwodarmito 1978, Kamus Besar Bahasa Indonesia,balai Pustaka, Jakarta, 1998. 